\title{
Prenatal cases with rare RIT1 variants causing severe fetal hydrops and death
}

\author{
Ieva Miceikaite ${ }^{1}$, Geske Bak², Martin Larsen $^{1}$, Britta Kristiansen ${ }^{1}$, and Pernille Torring ${ }^{1}$ \\ ${ }^{1}$ Odense Universitetshospital \\ ${ }^{2}$ Odense University Hospital
}

April 20, 2021

\begin{abstract}
Here we describe two clinical prenatal cases with rare de novo RIT1 variants which showed more severe clinical manifestations than other Noonan Syndrome genotypes, resulting in fetal death. It is recommended that extra attention would be exercised when these variants are detected, and an appropriate patient counselling would be provided.
\end{abstract}

Prenatal cases with rare RIT1 variants causing severe fetal hydrops and death

Ieva Miceikaite ${ }^{1,2}$, Geske Sidsel Bak ${ }^{3}$, Martin J. Larsen ${ }^{1,}$, Britta Schlott Kristiansen ${ }^{1}$, Pernille Mathiesen Torring ${ }^{1}$

${ }^{1}$ Department of Clinical Genetics, Odense University Hospital, Odense, Denmark

${ }^{2}$ Human Genetics Unit, Department of Clinical Research, Faculty of Health Sciences, University of Southern Denmark, Odense, Denmark

${ }^{3}$ Fetal Medicine Unit, Department of Obstetrics and Gynecology, Odense University Hospital, Odense, Denmark

*Correspondence: Geske Sidsel Bak geske.bak@rsyd.dk

The authors declare that there is no conflict of interest.

\section{Author Contributions :}

Ieva Miceikaite: Contributed to conception and design for this manuscript, collection of the data; wrote and edited the paper, prepared the table and the figure, and approved the final version to be published.

Geske Sidsel Bak: Contributed to conception and design; acquisition of data, including ultrasound pictures; and drafting the case descriptions. Revised the paper and approved the final version to be published.

Martin Jakob Larsen: Contributed to conception and design, performed the analysis and interpretation of the data, critically revised the draft, and approved the final version to be published.

Britta Schlott Kristiansen: Contributed to acquisition of the data, critically revised the draft, and approved the final version to be published.

Pernille Mathiesen Torring: Contributed to conception and design, and acquisition of data. Revised the paper and approved the final version to be published.

Abstract/ Key clinical message : 
Here we describe two clinical prenatal cases with rare de novoRIT1 variants which showed more severe clinical manifestations than other Noonan Syndrome genotypes, resulting in fetal death. It is recommended that extra attention would be exercised when these variants are detected, and an appropriate patient counselling would be provided.

Keywords : prenatal screening, Noonan syndrome, RIT1, cystic hygroma, hydrops fetalis

\section{INTRODUCTION}

Noonan Syndrome (NS) is a multisystemic developmental disorder with an incidence of 1:1000-2500 in the general population [1]. It follows an autosomal dominant inheritance. 30-75\% of patients with NS have an affected parent; nonetheless, NS can also be caused by a de novovariant. The disease has a wide spectrum of phenotypical features, which are associated with different genotypes. At present, 11 genes have been reported to cause NS when carrying a pathogenic variant [2]. Based on the chromosomal locations and genes involved, NS is divided into 12 types.

The RIT1 (Ras-Like Without CAAX 1) gene is associated with Noonan Syndrome type 8 (NS8, OMIM \#615355). The RIT1 gene is located on chromosome 1q22. The protein coded by RIT1 is involved in MAPKdependent signaling pathways (involved in stress-mediated activation of p38-MK2-HSP27-AKT complex in cell-survival mechanism) and NGF (Nerve Growth Factor) dependent nerve growth and differentiation [3]. Proteins coded by a mutated RIT1 gene cause hyperactivation of MAPK-ERK or transactivation of ELK pathways, participating in NS pathogenesis [3]. The gain-of-function mutations of RIT1 are responsible for around $5 \%$ of all NS cases, making RIT1 one of the most common genetic causes of NS [4].

The common distinctive characteristic in individuals with NS8 is hypertrophic cardiomyopathy, which is seen in at least $50 \%$ of the cases with a mutated RIT1 gene [4-6]. Congenital heart disease in NS gives one of the worst prognoses, as almost $25 \%$ of all NS patients die within a year due to heart failure [1]. Other more frequently observed characteristics among these patients are pulmonary stenosis and atrial or ventricular septal defects $[5,6]$.

Webbed and short neck is more common in RIT1 patients; however, short stature, pectus deformity, and intellectual disability are less common, compared to patients carrying mutations in other NS-associated genes $[3,7,8]$.

Prenatally, NS is suspected in cases with high nuchal translucency (NT), a cystic hygroma, or hydrops fetalis [9]. Prenatal lymphatic malfunctions are more often observed in RIT1 NS cases [5], which result in high birth weight and possible complications.

Here we describe two prenatally detected NS cases with pathogenic RIT1 variants, which resulted in severe fetal hydrops and death.

\section{PRESENTATION OF CASE 1}

A healthy nulliparous woman was referred to our tertiary fetal medicine clinic at the gestational age of (GA) $15^{+3}$ weeks. The family history revealed no congenital abnormalities and no consanguinity. The combined first trimester screening (cFTR) was done in the primary care center at GA $12^{+5}$. An ultrasound scan showed a cystic hygroma with NT of $14.2 \mathrm{~mm}$. The risk of Trisomy 21 was 1:8. Chorionic villus sampling (CVS) was done the following day. A normal male karyotype was reported in the chromosomal microarray. An early ultrasound of the fetal anatomy was performed at $15^{+3}$ that showed a persistent cystic hygroma with NT of $14 \mathrm{~mm}$ and large jugular lymphatic sacs at each side of the neck measuring $24 \mathrm{x} 16 \mathrm{~mm}$ for the left side and $20 \times 10 \mathrm{~mm}$ for the right side. The fetus was not hydropic.

The patient was offered a trio exome analysis and screened for variants in known Noonan-associated genes. At GA $19^{+5}$, another ultrasound of fetal anatomy was performed that showed smaller NT (12.4 mm) and jugular lymphatic sacs at both sides of neck, in the axial view of $7 \times 10 \mathrm{~mm}$ on the left side and $5 \times 8$ $\mathrm{mm}$ on the right side. No other malformations were observed. At GA $20^{+4}$, the sequencing result showed a de novo heterozygous pathogenic RIT1 variant (c.268A $>$ G (p.Met90Val), NM_006912.6). The couple was 
counseled about NS and their options. They decided to continue the pregnancy. At GA $28^{+6}$, an ultrasound showed normal growth with an estimated fetal weight of $1265 \mathrm{~g}$. The enlarged NT and jugular lymphatic sacs had disappeared. A new ultrasound was planned for GA 34, but the patient came in at GA $31^{+2}$ due to reduced fetal movements. Bilateral severe hydrothorax (chylothorax) was revealed by the ultrasound. The fetal echocardiography was normal. Betamethasone was given for lung maturation. The intrauterine drainage of the hydrothorax was only possible to insert at one side. It confirmed chylothorax. However, the fetus died in utero the day after the drainage was performed. It had hypertelorism and a broad webbed neck, but otherwise no characteristic Noonan features. The couple did not opt for autopsy. A postnatal picture and ultrasound scan findings can be seen in Figure 1 as Case 1.

\section{PRESENTATION OF CASE 2}

The patient was a nulliparous woman with a history of 2 years of infertility, but otherwise healthy, who became spontaneously pregnant. The family history contained no congenital abnormalities and no consanguinity. The combined first trimester screening was performed at $\mathrm{GA}_{1} 2^{+3}$, which showed a cystic hygroma with a large NT of $10.2 \mathrm{~mm}$ and mild cutaneous edema at the thorax and abdomen. The risk of Trisomy 21 was 1:3. She was informed about the risks of genetic diseases, fetal malformations, and intrauterine fetal demise. She was offered CVS and was informed about the option to apply for termination of the pregnancy. She chose CVS, and a normal chromosomal microarray result was received. Due to the residual risk of genetic disease, she was offered trio whole exome sequencing. An ultrasound of the fetal anatomy at GA $15^{+6}$ still showed a cystic hygroma with NT of $15 \mathrm{~mm}$. Furthermore, the fetus had pyelectasis of a slightly hyperechogenic left kidney.

At GA $18^{+2}$, a likely pathogenic, heterozygous de novo variant in the RIT1 gene (c.245T $>$ G (p.Phe82Cys), NM_006912.6) was detected by trio whole exome sequencing. The couple was counseled about NS. Ultrasound showed an NT of $18 \mathrm{~mm}$, bilateral pyelectasis, and mild ascites. The patient decided to continue the pregnancy and was evaluated with ultrasound every 1-2 weeks due to increasing fetal hydrops. At GA $19^{+6}$, there was bilateral pyelectasis (hydronephrosis). Fetal echocardiography was normal.

At GA $23^{+6}$, she developed mild polyhydramnios with an amnion fluid index (AFI) of $25 \mathrm{~cm}$. At GA $26^{+6}$, she still had mild polyhydramnios, but at GA $28^{+2}$, the polyhydramnios became severe, AFI $48 \mathrm{~cm}$, and it started to bother the patient. At the same time, fetal hydrops kept increasing with moderate to severe hydrothorax, and ascites that enlarged the abdominal circumference to +12 in Z-score, giving an estimated fetal weight of $3000 \mathrm{~g}$ (equivalent to $+130 \%$ of normal for the GA). The NT was $23 \mathrm{~mm}$ and the fetus had large jugular lymphatic sacs on each side of the neck. The flow in the umbilical cord had an absent-end diastolic flow. The patient was offered therapeutic amniocentesis after 48 hours of fetal lung maturation with betamethasone.

The patient came back at GA $28^{+6}$ for the amniocentesis and pediatric counseling. Her condition had worsened during the previous 24 hours; sleep problems and dyspnea had appeared due to the large uterus. Further testing showed Mirror syndrome resembling HELLP syndrome/preeclampsia. The amniocentesis was cancelled, and she had a subacute cesarean section. She was offered ex utero intrapartumtreatment (EXIT) with intubation of the baby during cesarean before clamping of the umbilical cord. She declined that option, but otherwise full treatment was planned. The newborn was severely hydropic at birth. It was intubated, ventilated, and given Curosurf ${ }^{\circledR}$ (poractant alfa). Bilateral pleural drainage was inserted. The treatment had no effect and resuscitation was terminated after 27 minutes; the newborn died shortly after. It was severely hydropic with flattened facies. The birth weight of $2935 \mathrm{~g}$ was equivalent to $+109 \%$ of normal for the GA and calculated to be $>10 \mathrm{SD}$, based on Hadlock [10]. The couple did not opt for autopsy of the newborn. A postnatal picture and ultrasound scan findings can be seen in Figure 1 as Case 2.

\section{DISCUSSION}

The two clinical prenatal cases described in this paper present rare RIT1 variants with similar, and differentthan-usual NS manifestations. Both variants are situated in the beginning of exon 5 of the RIT1 gene. The majority of known NS-associated pathogenic variants cluster in exons 4 and 5 (ClinVar)[5]. These variants 
(in switch II region of RIT1), described by Milosavljevic et al. [5], lead to a change of amino acid which is in a conserved sequence of the gene.

The RIT1 variant c.268A $>$ G (p.Met90Val) identified in Case 1, was previously detected in 4 prenatal cases, which all presented with hydrops fetalis (Table 1). In Case 2, a RIT1 variant c.245T $>$ G (p.Phe82Cys) was detected that was previously described once in a fetus with hydrops fetalis, CNS malformations, and congenital heart defect associated with NS [9].

A number of publications describe postnatally identified variants in the same codons as the two RIT1 variants in Cases 1 and 2; however, these involved different nucleotides and resulted in a different amino acid after substitution, which presented milder Noonan characteristic symptoms [7, 8, 11-13]. To the best of our knowledge, there are no exact postnatally identified variants described in the literature matching the two cases we present. For all the cases with prenatally identified variants in RIT1, matching the variants described in Cases 1 and 2, intrauterine fetal demise or death during labor was reported at GA 18-32 (Table 1). This suggests more severe clinical manifestations than other Noonan genotypes and a worse prognosis in cases with the RIT1 variants we have described in this case report.

A very recently published study, learning the genetic causes of non-immune hydrops fetalis, showed that $29 \%$ of the cases were solely due to gene variants in MAPK-dependent signaling pathways [14]. All of them were de novo variants, including a RIT1 variant. It indicates that Noonan-associated gene variants are a rather frequent finding in cases with hydrops fetalis. Furthermore, that study supports the use of exome sequencing for prenatal diagnosis in cases with hydrops fetalis as the ones described here.

Based on our described clinical cases and the outcomes of other recent studies, it is advised to remain attentive about the prognosis in cases where a cystic hygroma or hydrops fetalis and a rare de novo RIT1 variant are identified prenatally, as it might result in a more-severe-than-usual Noonan outcome resulting in fetal death. Thus, it is recommended that the patients be counselled about these potential risks.

\begin{tabular}{|c|c|c|c|c|c|c|c|}
\hline \multicolumn{2}{|c|}{ Characteristid C } & $\begin{array}{l}\text { Stevens et } \\
\text { al. } 2017 \\
\text { c. } 268 \mathrm{~A}>\mathrm{G}\end{array}$ & $\begin{array}{l}\text { Milosavljevic } \\
\text { et al. } 2016\end{array}$ & $\begin{array}{l}\text { Matyášová } \\
\text { et al. } 2019\end{array}$ & $\begin{array}{l}\text { Quinlan- } \\
\text { Jones et } \\
\text { al. } 2019 \\
\text { c. } 268 \mathrm{~A}>\mathrm{G}\end{array}$ & $\begin{array}{l}\text { Case 2 } \\
\text { c. } 245 \mathrm{~T}>\mathrm{G}\end{array}$ & $\begin{array}{l}\text { Yates et } \\
\text { al. 2017 } \\
\text { c. } 245 \mathrm{~T}>\mathrm{G}\end{array}$ \\
\hline $\begin{array}{l}\text { Genomic } \\
\text { RIT1 } \\
\text { variant } \\
(\mathrm{NM}- \\
0069 \overline{12.5})\end{array}$ & c. $268 \mathrm{~A}>\mathrm{G}$ & c. $268 \mathrm{~A}>\mathrm{G}$ & c. $268 \mathrm{~A}>\mathrm{G}$ & c. $268 \mathrm{~A}>\mathrm{G}$ & c. $268 \mathrm{~A}>\mathrm{G}$ & c. $245 \mathrm{~T}>\mathrm{G}$ & c. $245 \mathrm{~T}>\mathrm{G}$ \\
\hline $\begin{array}{l}\text { Protein } \\
\text { variant } \\
(\mathrm{NP}-\overline{-} \\
\mathbf{0 0 8 8 4 3 . 1})\end{array}$ & p.Met90Val & p.Met90Val & p.Met90Val & p.Met90Val & p.Met90Val & p.Phe82Cys & p.Phe82Cys \\
\hline De novo & + & + & + & + & + & + & + \\
\hline $\begin{array}{l}\text { Fetal } \\
\text { (prena- } \\
\text { tal) }\end{array}$ & $\begin{array}{l}\text { Fetal } \\
\text { (prena- } \\
\text { tal) }\end{array}$ & $\begin{array}{l}\text { Fetal } \\
\text { (prena- } \\
\text { tal) }\end{array}$ & $\begin{array}{l}\text { Fetal } \\
\text { (prena- } \\
\text { tal) }\end{array}$ & $\begin{array}{l}\text { Fetal } \\
\text { (prena- } \\
\text { tal) }\end{array}$ & $\begin{array}{l}\text { Fetal } \\
\text { (prena- } \\
\text { tal) }\end{array}$ & $\begin{array}{l}\text { Fetal } \\
\text { (prena- } \\
\text { tal) }\end{array}$ & $\begin{array}{l}\text { Fetal } \\
\text { (prena- } \\
\text { tal) }\end{array}$ \\
\hline $\begin{array}{l}\text { Increased } \\
\text { nuchal } \\
\text { translu- } \\
\text { cency }\end{array}$ & + & $\$$ & + & + & & + & \\
\hline $\begin{array}{l}\text { Cystic } \\
\text { hygroma }\end{array}$ & + & + & + & & + & + & + \\
\hline
\end{tabular}




\begin{tabular}{|c|c|c|c|c|c|c|c|}
\hline \multicolumn{2}{|c|}{ CharacteristidC $\mathbf{A s e s}$} & \multirow{2}{*}{$\begin{array}{l}\text { Stevens et } \\
\text { al. } 2017 \\
+\end{array}$} & \multirow{2}{*}{$\begin{array}{l}\text { Milosavljevic } \\
\text { et al. } 2016 \\
+\end{array}$} & \multirow[t]{2}{*}{$\begin{array}{l}\text { Matyášová } \\
\text { et al. } 2019\end{array}$} & \multirow[t]{2}{*}{$\begin{array}{l}\text { Quinlan- } \\
\text { Jones et } \\
\text { al. } 2019\end{array}$} & \multirow{2}{*}{$\frac{\text { Case } 2}{+}$} & \multirow[t]{2}{*}{$\begin{array}{l}\text { Yates et } \\
\text { al. } 2017\end{array}$} \\
\hline $\begin{array}{l}\text { Large } \\
\text { jugular } \\
\text { lym- } \\
\text { phatic } \\
\text { sacs }\end{array}$ & + & & & & & & \\
\hline $\begin{array}{l}\text { Hydrops } \\
\text { fetalis }\end{array}$ & + & + & $+\alpha$ & + & + & + & + \\
\hline $\begin{array}{l}\text { bilateral } \\
\text { hydrotho- } \\
\text { rax/ } \\
\text { pleural } \\
\text { effusion }\end{array}$ & + & + & + & & & + & \\
\hline ascites & no & & + & + & + & + & \\
\hline $\begin{array}{l}\text { skin } \\
\text { edema }\end{array}$ & no & & & & + & + & \\
\hline $\begin{array}{l}\text { severe } \\
\text { general- } \\
\text { ized } \\
\text { edema/ } \\
\text { anasarca }\end{array}$ & no & + & + & & & + & \\
\hline $\begin{array}{l}\text { Hydronephr } \\
\text { pyelectasis }\end{array}$ & $\operatorname{si\theta } /$ & + & $*$ & & & $+¥$ & \\
\hline $\begin{array}{l}\text { Flattened } \\
\text { facies }\end{array}$ & no & + & & & & + & \\
\hline $\begin{array}{l}\text { Cardiac } \\
\text { defect }\end{array}$ & no & no & no & & & no & + \\
\hline $\begin{array}{l}\text { CNS } \\
\text { malfor- } \\
\text { mations }\end{array}$ & no & no & no & & & no & $+\S$ \\
\hline $\begin{array}{l}\text { Maternal } \\
\text { Polyhydram } \\
\text { Amnioreduc } \\
\text { procedure }\end{array}$ & $\begin{array}{l}\text { Maternal } \\
\text { ioss } \\
\text { imm }\end{array}$ & $\begin{array}{l}\text { Maternal } \\
+ \\
\text { several }\end{array}$ & $\begin{array}{l}\text { Maternal } \\
+ \\
\text { once }\end{array}$ & Maternal & Maternal & $\begin{array}{l}\text { Maternal } \\
+ \\
\text { planned }\end{array}$ & Maternal \\
\hline $\begin{array}{l}\text { HELLP } \\
\text { syndrome/ } \\
\text { preeclamp- } \\
\text { sia/ } \\
\text { Mirror } \\
\text { syndrome }\end{array}$ & no & no & + & & & + & \\
\hline $\begin{array}{l}\text { Fetal death } \\
\text { (GA) }\end{array}$ & $31+5$ IUFD & 30 IUFD & $\begin{array}{l}26+4 \text { during } \\
\text { labor }\end{array}$ & IUFD & IUFD & $\begin{array}{l}28+6 \text { after } \\
\mathrm{CS}\end{array}$ & 18 \\
\hline $\begin{array}{l}\text { Fetal/child } \\
\text { (postna- } \\
\text { tal) }\end{array}$ & $\begin{array}{l}\text { Fetal/child } \\
\text { (postna- } \\
\text { tal) }\end{array}$ & $\begin{array}{l}\text { Fetal/child } \\
\text { (postna- } \\
\text { tal) }\end{array}$ & $\begin{array}{l}\text { Fetal/child } \\
\text { (postna- } \\
\text { tal) }\end{array}$ & $\begin{array}{l}\text { Fetal/child } \\
\text { (postna- } \\
\text { tal) }\end{array}$ & $\begin{array}{l}\text { Fetal/child } \\
\text { (postna- } \\
\text { tal) }\end{array}$ & $\begin{array}{l}\text { Fetal/child } \\
\text { (postna- } \\
\text { tal) }\end{array}$ & $\begin{array}{l}\text { Fetal/child } \\
\text { (postna- } \\
\text { tal) }\end{array}$ \\
\hline $\begin{array}{l}\text { High } \\
\text { (birth) } \\
\text { weight }\end{array}$ & no & & $>2.5 \mathrm{SD}$ & & & $>10 \mathrm{SD}$ & \\
\hline Hyperteloris & & & + & & & & \\
\hline
\end{tabular}




\begin{tabular}{|c|c|c|c|c|c|c|}
\hline \multicolumn{2}{|c|}{ Characteristic $d$} & \multirow[t]{2}{*}{$\begin{array}{l}\text { Stevens et } \\
\text { al. } 2017\end{array}$} & \multirow{2}{*}{$\begin{array}{l}\text { Milosavljevic Matyášová } \\
\text { et al. } 2016 \quad \text { et al. } 2019\end{array}$} & \multirow[t]{2}{*}{$\begin{array}{l}\text { Quinlan- } \\
\text { Jones et } \\
\text { al. } 2019\end{array}$} & \multirow{2}{*}{$\begin{array}{l}\text { Case } 2 \\
\text { no }\end{array}$} & \multirow[t]{2}{*}{$\begin{array}{l}\text { Yates et } \\
\text { al. } 2017\end{array}$} \\
\hline $\begin{array}{l}\text { Low set } \\
\text { ears }\end{array}$ & no & & & & & \\
\hline $\begin{array}{l}\text { Broad } \\
\text { short } \\
\text { webbed } \\
\text { neck }\end{array}$ & + & & + & & + & \\
\hline Other & & & & $\mathrm{p}$ & $*$ & \\
\hline $\begin{array}{l}\text { Pathological } \\
\text { examina- } \\
\text { tion }\end{array}$ & NP & & NP & + & NP & \\
\hline
\end{tabular}

Table 1. Prenatal and postnatal fetal as well as maternal phenotypic characteristics and clinical outcome for two cases described here, and other published cases with corresponding identical variants in RIT1 gene.

+- the characteristic was present, no - the characteristic was not present, an empty square - no information, GA - gestational age in weeks, CS - caesarian section, NP - not permitted/not performed, ${ }^{*}$ - duplication of renal collection system, $¥-$ hyperechogenic left kidney, $\S-$ Dandy-Walker malformation, $\$-$ cFTR not performed, 1st scan at GA 21, $\not \alpha$ - severe at GA 25, p - superior vena cava, atrial septal defect, bilateral talipes.

If GA or other information about the fetal demise is not written, it is unknown or not provided by the authors.

\section{REFERENCES}

1. Roberts, A.E., et al., Noonan syndrome. Lancet, 2013.381 (9863): p. 333-42.

2. Cai, J. and H. Li, A novel RIT1 mutation causes deterioration of Noonan syndrome-associated cardiac hypertrophy. EBioMedicine, 2019.42 : p. 6-7.

3. Cave, H., et al., Mutations in RIT1 cause Noonan syndrome with possible juvenile myelomonocytic leukemia but are not involved in acute lymphoblastic leukemia. Eur J Hum Genet, 2016. 24 (8): p. 1124-31.

4. Aoki, Y., et al., Recent advances in RASopathies. J Hum Genet, 2016. 61 (1): p. 33-9.

5. Milosavljevic, D., et al., Two cases of RIT1 associated Noonan syndrome: Further delineation of the clinical phenotype and review of the literature. Am J Med Genet A, 2016. 170 (7): p. 1874-80.

6. Calcagni, G., et al., Congenital heart defects in Noonan syndrome and RIT1 mutation. Genet Med, 2016. 18 (12): p. 1320.

7. Yaoita, M., et al., Spectrum of mutations and genotype-phenotype analysis in Noonan syndrome patients with RIT1 mutations. Hum Genet, 2016. 135 (2): p. 209-22.

8. Bertola, D.R., et al., Further evidence of the importance of RIT1 in Noonan syndrome. Am J Med Genet A, 2014. 164A (11): p. 2952-7.

9. Yates, C.L., et al., Whole-exome sequencing on deceased fetuses with ultrasound anomalies: expanding our knowledge of genetic disease during fetal development. Genet Med, 2017. 19 (10): p. 1171-1178.

10. Hadlock, F.P., et al., Estimation of fetal weight with the use of head, body, and femur measurements-a prospective study. Am J Obstet Gynecol, 1985. 151 (3): p. 333-7. 
11. Aoki, Y., et al., Gain-of-function mutations in RIT1 cause Noonan syndrome, a RAS/MAPK pathway syndrome. Am J Hum Genet, 2013.93 (1): p. 173-80.

12. Gos, M., et al., Contribution of RIT1 mutations to the pathogenesis of Noonan syndrome: four new cases and further evidence of heterogeneity. Am J Med Genet A, 2014. 164A (9): p. 2310-6.

13. Kouz, K., et al., Genotype and phenotype in patients with Noonan syndrome and a RIT1 mutation. Genet Med, 2016. 18 (12): p. 1226-1234.

14. Sparks, T.N., et al., Exome Sequencing for Prenatal Diagnosis in Nonimmune Hydrops Fetalis. N Engl J Med, 2020. 383 (18): p. 1746-1756.

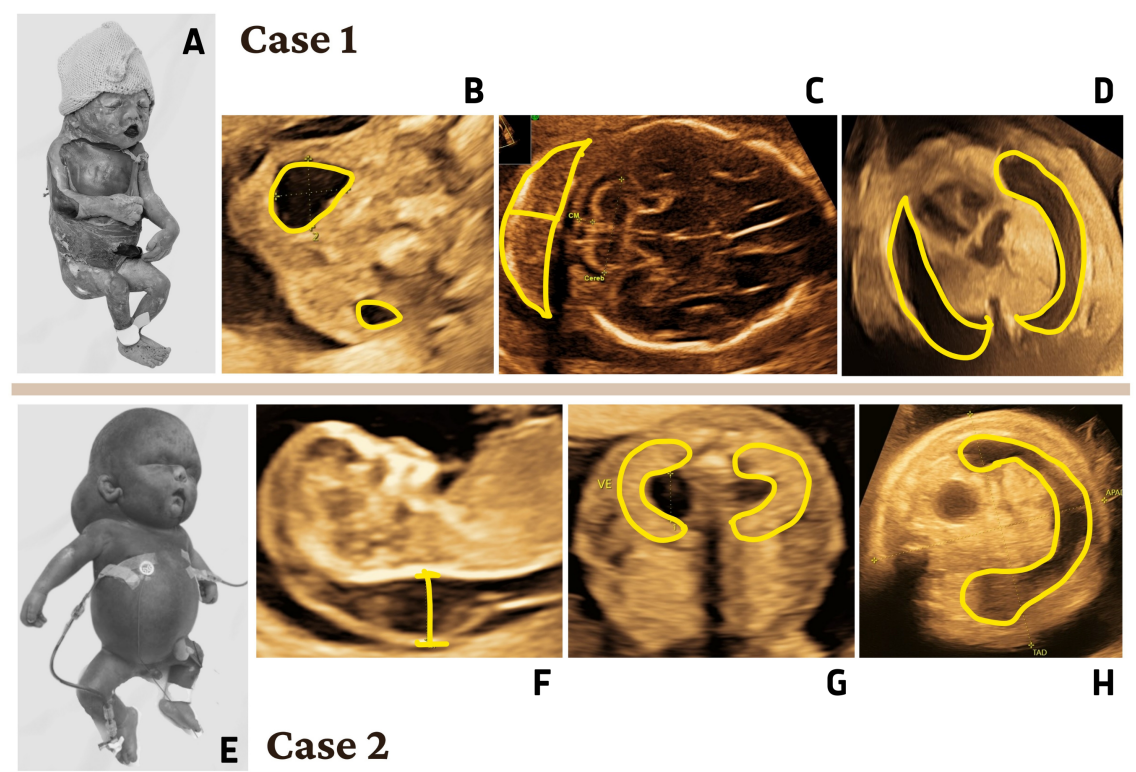

